\title{
Geographically uneven structural change in EU15 regions from 1980 to 2017: a cluster analysis
}

Working paper 01/22

February 2022

Sanne Velthuis, Jeroen Royer, Mehdi Le PetitGuerin, Nicolas Cauchi-Duval, Rachel Franklin, Tim Leibert, Danny MacKinnon, Andy Pike 


\section{Acknowledgements}

This working paper is an output from the project "Beyond 'Left Behind Places': Understanding Demographic and Socio-economic Change in Peripheral Regions in France, Germany and the UK" (grant reference ES/V013696/1), funded by the Economic and Social Research Council (ESRC), L'Agence Nationale de la Recherche (ANR), and the Deutsche Forschungsgemeinschaft (DFG). We are grateful to the funders for their support.

Centre for Urban and Regional Development Studies (CURDS)

Newcastle University

Newcastle upon Tyne, NE1 7RU

United Kingdom

\section{https://research.ncl.ac.uk/beyondleftbehindplaces/}

@PeripheralPlace

To cite this paper:

Velthuis, S., Royer, J., Le Petit-Guerin, M., Cauchi-Duval, N., Franklin, R., Leibert, T., MacKinnon, D., Pike, A. (2022) Geographically uneven structural change in EU15 regions from 1980 to 2017: a cluster analysis. Beyond Left Behind Places Project Working Paper 01/22. Centre for Urban and Regional Development Studies (CURDS), Newcastle University, UK. DOI: 


\title{
Geographically uneven structural change in EU15 regions from 1980 to 2017: a cluster analysis
}

\author{
Sanne Velthuis*, Jeroen Royer**, Mehdi Le Petit-Guerin***, Nicolas Cauchi-Duval***, \\ Rachel Franklin*, Tim Leibert**, Danny MacKinnon*, Andy Pike* \\ * Centre for Urban and Regional Development Studies (CURDS), Newcastle University \\ ** Leibniz-Institut für Länderkunde \\ *** Sociétés, Acteurs, Gouvernement en Europe (SAGE), Université de Strasbourg
}

\begin{abstract}
This paper presents a cluster analysis of structural economic change within NUTS3 regions in the EU15. Based on regional changes in the employment shares of broad sectors since 1980, as well as the degree of initial and current specialisation in each sector, regions are allocated to one of eight clusters via a k-means clustering approach. These clusters are then interpreted in light of current debates about left behind places'. We find that there are several clusters of regions that have experienced less favourable structural change over the past four decades, each with their own set of characteristics.
\end{abstract}

\section{Introduction: the importance of structural economic change for European regions}

There have been fundamental changes in the economic structures of European regions over the last several decades. These shifts are important to understand in light of debates about regions which have been 'left behind' by technological change and globalisation and marginalised by the increasing concentration of skilled jobs in cities (Kühn, 2015; MacKinnon et al., 2021). For instance, the (continued) decline of the manufacturing sector in many regions across Europe is cited as one of the factors behind the rise of political disenchantment and discontent in recent decades (Baccini \& Weymouth, 2021; Caselli et al., 2021; Essletzbichler et al., 2018; Rodríguez-Pose, 2018).

As well as the process of deindustrialisation, the extent to which regions have managed to expand activity in knowledge-intensive, high value-added, tradeable services, versus relying on growth in lower value-added, non-tradable services, has been important for their economic, social and political fortunes (Florida, 2021; lammarino et al., 2017; Martin, 2015). In particular, there is concern that employment growth in certain regions has increasingly been in relatively low value-added sectors characterised by lower-paid, lowerquality employment (Capello \& Fratesi, 2013; Consoli \& Sánchez-Barrioluengo, 2019). These shifts have implications not only for productivity growth and thus the performance of the regional economy (Tyler et al., 2017), but also for the employment opportunities, conditions and living standards of people working in these regions.

This working paper analyses the changing economic structures of EU15 regions from 1980 to 2017 , using a cluster analysis to group regions according to both their initial sectoral structures and the changes in these structures over the subsequent 37 years. The aim is to identify clusters of regions that have experienced similar patterns of sectoral change, 
including clusters that are characterised by less favourable forms of structural transition (or lack thereof). The analysis is designed to enable an exploration of the heterogeneity that exists within both structurally advantaged and structurally weaker regions, in line with other analysis that emphasises the existence of a variety of different types of 'left behind' places (Martin et al., 2021). Through the analysis several types of regions are identified that could be described as less structurally advantaged, including: regions affected by large-scale deindustrialisation; regions characterised by a reliance on public sector employment in the absence of a strong tradeable economy; and regions characterised by a high and/or growing presence of low value-added service activities such as retail and hospitality. The identification of these groups of regions as relatively distinct clusters illustrates the variegation that exists when it comes to structural change at the regional level.

\section{Data}

For this analysis, we measure the sectoral structure of the regional economy based on employment, rather than output, because the former is likely to be of more direct relevance in shaping the economic opportunities for people living and working in the region in question. Our data come from the Annual Regional Database of the European Commission's Directorate General for Regional and Urban Policy (ARDECO). The data series used is 'Employment by NACE Sector', which breaks down total employment in all NUTS3 regions into six (groups of) NACE (Nomenclature statistique des Activités économiques dans la Communauté Européenne) sectors ${ }^{1}$ :

- agriculture (NACE sector $A$ ),

- industry (NACE sectors B-E) ${ }^{2}$,

- construction (NACE sector F),

- other private services (NACE sectors G-J),

- financial and business services (NACE sectors K-N), and

- public sector (referred to as 'non-market services' by ARDECO) (NACE sectors O-U) ${ }^{3}$.

Of these six sectors, we only use four: industry; financial and business services; other private services; and the public sector. The sector labelled 'other private services' is composed of the sub-sectors wholesale and retail; accommodation and food services; transport and storage; and information and communication. Of these, wholesale and retail is by far the biggest sector across the EU15, followed by the accommodation and food service sector (also referred to as the hospitality sector) (Eurostat, 2022).

Two sectors are left out of the analysis. Agriculture is not included because the employment data for this sector is either incomplete or lacking in precision for many UK regions, meaning we would lose these regions from the cluster analysis if agriculture is included. ${ }^{4}$ It additionally tends to be a very small sector in employment terms. The construction sector is

\footnotetext{
${ }^{1}$ Although the six categories used by ARDECO are a combination of individual sectors and groups of sectors, the term 'sector' is used for all six in the rest of this paper.

2 This broad sector includes mining and quarrying; electricity, gas, steam and air-conditioning supply; and water supply, sewerage, waste management and remediation.

${ }^{3}$ This final group isn't strictly limited to non-market services, since it also includes the sectors 'Arts, Entertainment and Recreation' and 'Other Service Activities'. However, the sectors 'Public Administration and Defence, Compulsory Social Security', 'Education', and 'Human health Services and Residential Care and Social Work Activities' make up the majority of employment in this group. ${ }^{4}$ Due to the rounding used in the UK employment data after the year 2000, it is unfortunately not possible to reliably calculate agricultural employment using total employment and employment in each of the other sectors.
} 
excluded because, like the agricultural sector, it tends to be small in size, and we want to prevent this small sector from having an outsized influence on the results, particularly because of the ambiguity inherent in interpreting its role in structural change. ${ }^{5}$ Appendix $A$ has more detail on how the results differ when these two sectors are included in the analysis. Employment is counted at the region of work, and so the data refer to the sectoral mix of workers employed in each region rather than those living in the region, although in many cases a considerable proportion of regional workers are likely to be resident in the same NUTS3 region.

We use data for the years 1980 and 2017 (the latest available complete data at the time of writing). We use 1980 as our starting point because for many regions the 1980 s were an important decade in terms of structural change, especially with regards to the growth of financial and business services. Particularly in the UK, there are regions in which more than half of the total growth in financial and business services seen between 1980 and 2017 occurred during the 1980s. Because no data is available for eastern German regions before 1991 , the choice of 1980 as our starting point does mean that these areas (which account for 19 per cent of German regions) are omitted from the analysis. Furthermore, we exclude the French overseas territories, but include the Canary Islands, Azores and Madeira. In total our sample contains 1,023 NUTS3 regions.

\section{Methods}

\section{Input variables for cluster analysis}

To measure sectoral change, we subtract each sector's employment share in 1980 from its employment share in 2017, in order to arrive at the change in that sector's share of overall employment, expressed in percentage points. The reason for measuring sectoral change as the difference between a sector's employment share in 1980 and its employment share in 2017 , rather than as a proportion of the sector's initial employment share, is because we're interested in the effect of changes in the size of each sector on the overall composition of regional employment, and because we want to prevent small sectors that experience large changes in employment as a proportion of their initial size from having a disproportionate effect on the results.

Although the aim of the analysis is to capture sectoral change, we also include the employment share of each sector in 1980, and its share of employment in 2017, as inputs in the cluster analysis. This is because in evaluating sectoral change, the initial sectoral composition of regions also matters. For instance, the same amount of decline in industrial employment will have different impacts depending on the initial size of the industrial sector as a share of the overall economy, and the same is true for growth or decline in other sectors. Unlike other analyses (Capello \& Fratesi, 2013), we measure how the sectoral composition of the regional workforce compares to the national sectoral mix, using location quotients. The reason for this is to remove national differences in sectoral structure from consideration in order to identify groups of regions that have experienced similar structural shifts relative to their country as a whole. The changing role that regions play in their national economic structure is likely to be a more salient reference point when it comes to shaping perceptions of being 'left behind' or not than how they compare to the economic structure of the EU15 as a whole (Hüther \& Südekum, 2019; Martin et al., 2021). Moreover, regional

\footnotetext{
${ }^{5}$ The construction accounted for 8.7 per cent of employment across the EU15 in 1980, and 6.1 per cent in 2017. The agricultural sector accounted for 8.7 per cent of employment in 1980 and 2.1 per cent in 2017.
} 
differences within the same country are likely to have greater relevance than differences between countries when it comes to individual decisions about residential (im)mobility, since people are more likely to consider relocating to another region within their current member state than to another country. To calculate the location quotients for each sector, the regionlevel employment shares are divided by the employment share of the relevant sector at the national level, and the resulting measure is thus an indicator of the extent to which a sector is over- or under-represented in the region relative to the national sectoral structure.

To summarise, the input variables to the clustering are the following:

- Location quotients 1980:

- Industry

- Financial \& business services

- Public sector

- Other private services

- Change in employment share (in percentage points):

$\circ$ Industry

- Financial \& business services

- Public sector

- Other private services

- Location quotients 2017:

- Industry

- Financial \& business services

- Public sector

- Other private services

\section{Clustering approach}

Using these input variables, a cluster analysis was conducted to group NUTS3 regions into clusters that share similar combinations of characteristics. Though in regional analysis, hierarchical clustering methods are sometimes used (Aumayr, 2006; Hedlund, 2016; Kronthaler, 2005), here a k-means approach was chosen since it was found to result in more intuitive and well-defined clusters and to be less sensitive to outliers. K-means clustering is an oft-used technique in analysis of neighbourhood types (Delmelle, 2016; Patias et al., 2021; Wei \& Knox, 2014).

The aim of k-means clustering is to assign objects to a predetermined number of clusters $(\mathrm{k})$ such that within-cluster variance is minimised and between-cluster variance is maximised. ${ }^{6}$ To achieve this, the k-means method uses an iterative cycle of steps. First, a predefined number of data points are randomly selected to act as initial cluster centroids and each data point is assigned to its nearest centroid. Then, the cluster centroids are moved, such that the sum of the squared Euclidean distances between the centroid and the data points assigned to that centroid is minimised. Each data point is again assigned to its nearest centroid, and the cycle starts again. These steps are repeated until each data point is assigned to its 'optimal' centroid and the centroid positions are stable.

Because the exact solution found by the k-means algorithm varies depending on the initial position of the cluster centroids, we use a modification that involves taking multiple sets of starting positions and selecting the 'best' set, i.e. the set that minimises the total squared

\footnotetext{
${ }^{6}$ More precisely, minimising within-cluster variance (i.e. the sum of the squared distances between each data point in a cluster and the cluster centroid) is the aim that the k-means algorithm was designed for and the aim that it is mostly used for, but the same algorithm can be used to achieve aims other than this (Fränti \& Sieranoja, 2019).
} 
sum of distances, as the starting point for the iterative cycle. Fränti and Sieranoja (2019) find that this technique, sometimes called repeated k-means or multi-start k-means, tends to lead to significant improvement in the performance and stability of the k-means algorithm.

As no definitive criterion exists to determine the 'right' number of clusters, an elbow plot and silhouette plot were examined. These both suggested that an eight-cluster solution represented a good balance between separation of clusters and the amount of overall variance explained, while maintaining a manageable number of clusters. Even with eight clusters, only 44.4 per cent of the total variance (sum of squares) is explained, attesting to the degree of heterogeneity across EU15 regions in terms of sectoral structure and change, and the inherent difficulty in capturing the multidimensional nature of structural change in a small number of clusters.

\section{Results: distinct patterns of structural change as identified through cluster analysis}

Table 1 shows the number of regions that are part of each cluster, along with cluster mean values on each of the indicators used. Each cluster clearly displays a distinct combination of sectoral location quotients and sectoral shifts over time.

Table 1: Cluster mean values on each indicator

\begin{tabular}{|c|c|c|c|c|c|c|c|c|}
\hline & Cluster 1 & Cluster 2 & Cluster 3 & Cluster 4 & Cluster 5 & Cluster 6 & Cluster 7 & Cluster 8 \\
\hline \multicolumn{9}{|l|}{ Location quotients 1980} \\
\hline Industry & 1.6 & 1.2 & 0.7 & 0.7 & 0.8 & 1.0 & 0.7 & 0.6 \\
\hline Fin. \& bus. services & 0.7 & 0.6 & 0.6 & 1.0 & 2.0 & 0.9 & 1.0 & 0.7 \\
\hline Public sector & 0.8 & 0.9 & 1.5 & 1.0 & 0.8 & 1.1 & 1.0 & 0.8 \\
\hline Other private services & 0.8 & 0.8 & 0.9 & 1.4 & 0.9 & 1.1 & 1.4 & 0.8 \\
\hline \multicolumn{9}{|l|}{ Change in empl. share } \\
\hline Industry & -25.0 & -7.5 & -7.5 & -9.0 & -10.2 & -14.1 & -7.7 & -3.2 \\
\hline Fin. \& bus. services & 8.1 & 6.1 & 6.2 & 4.0 & -3.3 & 10.5 & 5.6 & 4.6 \\
\hline Public sector & 12.3 & 7.4 & 3.6 & 16.6 & 12.8 & 7.7 & 5.0 & 13.8 \\
\hline Other private services & 8.5 & 4.9 & 5.7 & -5.9 & 8.5 & 2.3 & 6.6 & 10.3 \\
\hline \multicolumn{9}{|l|}{ Location quotients 2017} \\
\hline Industry & 1.4 & 1.7 & 0.9 & 0.7 & 0.8 & 0.9 & 0.7 & 0.9 \\
\hline Fin. \& bus. services & 0.8 & 0.7 & 0.7 & 0.9 & 1.2 & 1.0 & 0.9 & 0.6 \\
\hline Public sector & 1.0 & 0.9 & 1.2 & 1.2 & 1.0 & 1.0 & 0.9 & 1.0 \\
\hline Other private services & 1.0 & 0.9 & 1.0 & 1.0 & 1.0 & 1.0 & 1.3 & 0.9 \\
\hline Number of regions & 147 & 216 & 165 & 81 & 46 & 177 & 59 & 132 \\
\hline Percentage of regions & 14.4 & 21.1 & 16.1 & 7.9 & 4.5 & 17.3 & 5.8 & 12.9 \\
\hline $\begin{array}{l}\text { Population in } 2017 \\
\text { (million) }\end{array}$ & 64.2 & 55.0 & 39.0 & 21.9 & 22.6 & 122.4 & 24.0 & 16.2 \\
\hline $\begin{array}{l}\text { Percentage of total } \\
\text { EU15 population }\end{array}$ & 17.6 & 15.0 & 10.7 & 6.0 & 6.2 & 33.5 & 6.6 & 4.4 \\
\hline
\end{tabular}

Source: Authors' analysis based on ARDECO data on employment by NACE sector. Darker colour = higher location quotient/increase in employment share, except for change in industry where a darker colour indicates a larger decrease in the employment share of industry (given that the overall trend for this period is one of deindustrialisation). 
Figure 1 shows the geographic distribution of the clusters across the EU15.

\section{Figure 1: Cluster assignment of all NUTS3 regions in the EU15}

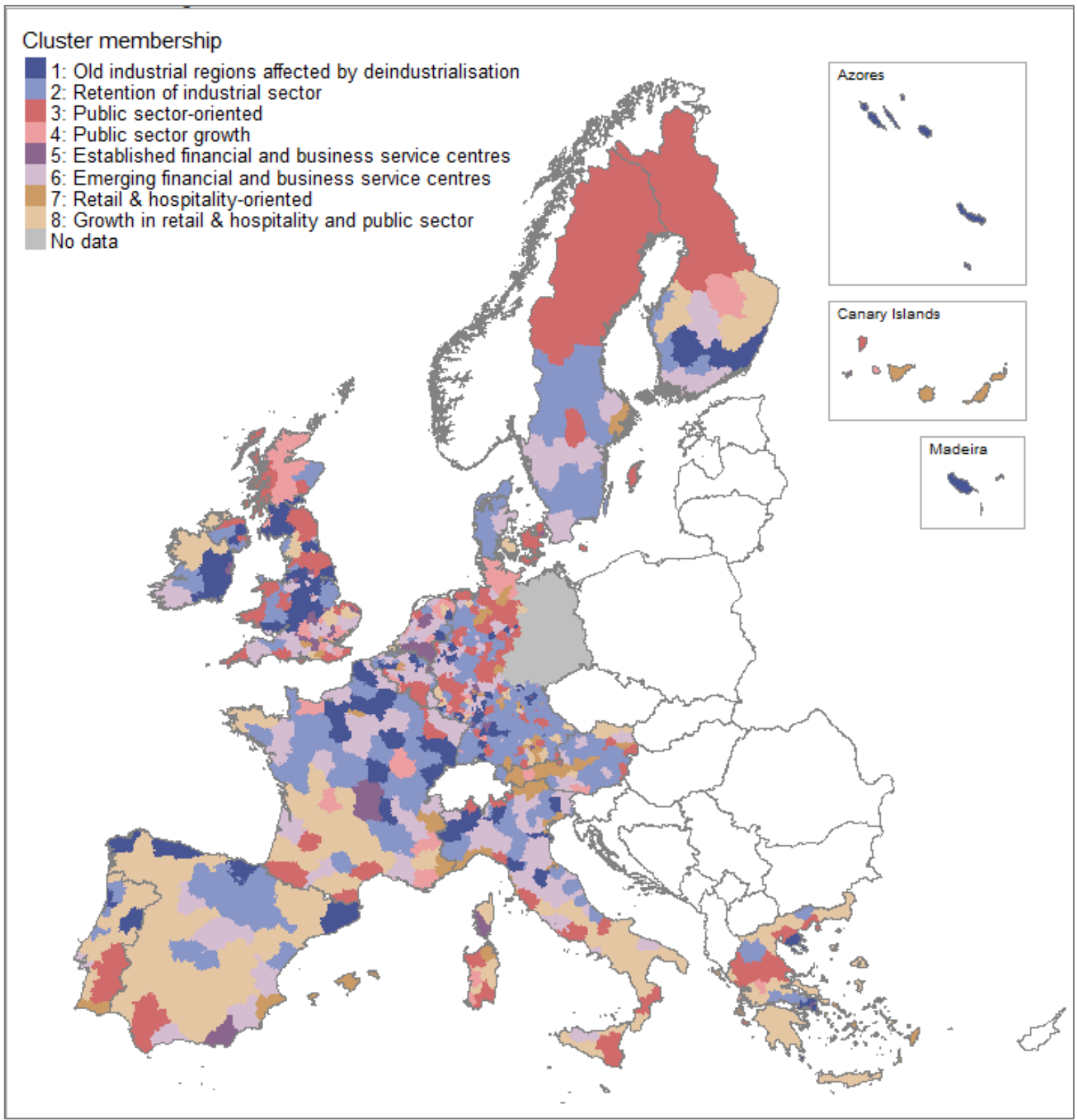

Source: Authors' analysis based on ARDECO data on employment by NACE sector. Source of administrative boundaries is EuroGeographics.

\section{Cluster descriptions}

Below we describe the main characteristics of each of the eight clusters, based on the mean values for each indicator shown in Table 1. It is important to bear in mind that there often is substantial within-cluster variety, so the regions in a particular cluster will vary in certain ways from the general pattern seen for that cluster as a whole. 


\section{Cluster 1: Old industrial regions affected by deindustrialisation}

In 1980 these regions were heavily specialised in industry, but between 1980 and 2017 they tended to see a very substantial reduction in their industrial employment share. This fall in industrial employment was accompanied by a relative increase in the employment share of the public sector in particular. In 2017 these regions still had an above-average share of employment in industry compared to their nation as a whole, with a lower-than-average share of employment in financial and business services. Example regions include Charleroi (Belgium), Herne (Germany), Loire (France), Torino (Italy), and Wolverhampton (UK).

\section{Cluster 2: Retention of industry}

These regions also had an overrepresentation of industrial employment in 1980, but less so than regions in cluster 1. Over the next four decades, these regions experienced a much more modest decline in industrial employment than regions in cluster 1 , and as a result this cluster had overtaken the first cluster as the one with the highest industrial specialisation in 2017. Example regions include Innviertel (Austria), Donnersbergkreis (Germany), Morbihan (France) and West Cumbria (UK).

\section{Cluster 3: Public sector-oriented}

Regions in this cluster were characterised by a large initial share of public sector employment. They tended to experience a slight reduction in the relative size of the public sector between 1980 and 2017. However, at the end of the period they still retained a higher-than-average share of employment in this sector. These regions tended to see average growth in the share of employment in financial and business services and in other private services. Example regions include Hérault (France), Birkenfeld (Germany), Västerbottens län (Sweden), Cagliari (Italy) and Blackpool (UK).

\section{Cluster 4: Public sector growth}

These regions share a similarity with regions in cluster 3 in the sense of having an overrepresentation of public sector employment in 2017, compared to their country overall. However, unlike regions in cluster 3 , this overrepresentation was the result of strong growth in public sector employment over time, rather than an initially high employment share in this sector. In fact, these regions started off being specialised in the 'other private services' sector more so than the public sector. Example regions include Nordfriesland (Germany), Haute-Vienne (France), Zuidwest-Drenthe (Netherlands), and the Shetland Islands (UK).

\section{Cluster 5: Established financial and business service centres}

Regions in this cluster are characterised by a very high location quotient for financial and business services in 1980, but a decline in the employment share of this sector over the subsequent four decades. As a result, the location quotient for financial and business services in these regions had, on average, substantially reduced by 2017 , though the sector remained overrepresented in these regions. Alongside a moderate decline in financial and business service employment, these regions tended to see an increase in the share of employment in the public sector as well as in other private services. Example regions include Camden \& City of London (UK), München (Germany), West-Noord-Brabant (Netherlands), and Dublin (Ireland).

\section{Cluster 6: Emerging financial and business service centres}

This is the largest cluster both in terms of number of regions and population. Unlike cluster 5 , this cluster started off with a slight underrepresentation of financial and business service 
employment in 1980 compared to the national share of this sector. However, from 1980 to 2017 these regions tended to see strong growth in financial and business services, the strongest growth in fact of any of the eight clusters. As a result, in 2017 the financial and business service location quotient of these regions was, on average, greater than 1 , indicating that these regions may be becoming more specialised in this sector. This cluster is comprised of mostly urban regions, including several large metropolitan areas. However, it also includes a fair number of regions defined by Eurostat as 'intermediate' (Eurostat, 2020). Example regions include Hautes-de-Seine (France), Groot-Amsterdam (Netherlands), Glasgow (UK), Gent (Belgium), and Bologna (Italy).

\section{Cluster 7: Retail \& hospitality-oriented}

In 1980 these regions had large location quotients for other private services, and due to moderate growth in this sector over time they retained this characteristic up to 2017 ; in fact in 2017 these regions had the largest specialisation in other private services of all clusters. This sector, as described above, includes retail, hospitality, and transport - sub-sectors that tend to be characterised by lower-than-average productivity and wages. These regions tended to see only moderate growth in employment in financial and business services and in the public sector between 1980 and 2017, and as a result these sectors tended to make up a smaller share of the regional economy in 2017 than in 1980. This cluster contains a mix of smaller cities, intermediate regions and rural regions. Example regions include Tiroler Oberland (Austria), Tenerife (Spain), Alpes-Maritimes (France), and Rimini (Italy).

\section{Cluster 8: Growth in retail \& hospitality and public sector}

These regions had a lower-than-average share of employment in all four sectors in 1980. A complementary examination of their average employment share in agriculture indicates that they initially specialised in agriculture, but that this specialisation declined over time. At the same time, these regions experienced large increases in employment in other private services (again, a sector dominated by wholesale and retail as well as, to a lesser extent, hospitality), as well as in the public sector, but relatively low growth in financial and business services. In 2017, this cluster had the largest underrepresentation of financial and business service employment of all the clusters. This cluster is the most rural of all the clusters, and contains many peripheral regions in southern Europe. Example regions include Pieria (Greece), Cuenca (Spain), Gard (France), Lecce (Italy) and Oeste (Portugal).

\section{Geographic distribution of clusters across countries}

As shown in Table 2, no cluster is confined to just one or a small number of countries, but instead each cluster is observed across most EU15 countries. To take one example, regions characterised by large-scale deindustrialisation (cluster 1) can be found in Finland, Ireland, the UK, the Netherlands, Belgium, France, Germany, Austria, Spain, Italy and Greece. ${ }^{7}$ This doesn't necessarily imply a convergence in the sectoral structures of EU15 regions (nor, for that matter, divergence), it just means that the same patterns of sectoral change can be found in regions across multiple member states. For instance, the Italian region of Biella and the UK region of Calderdale and Kirklees share a similar history of extensive industrial

\footnotetext{
${ }^{7}$ Of course, the clustering is based on measures of sectoral structure relative to the national structure of employment, so the absolute size of the industrial sector (as a share of employment) in 1980 and 2017 does vary between cluster 1 member regions located in different countries. For instance, in western German regions belonging to cluster 1 the industrial sector shrank, on average, from 50 per cent to 24 per cent of regional employment, but in Irish regions belonging to cluster 1 the decline was somewhat less severe, from 30 per cent to 14 per cent of employment. Nonetheless, across all countries, cluster 1 regions experienced considerable industrial employment loss.
} 
employment loss and a tendency for this loss to be compensated by employment in the public sector and in other private services more so than in financial and business services.

There are, however, also notable differences between EU15 countries in terms of the types of clusters found. Cluster 1 (Old industrial regions affected by deindustrialisation) is the most prevalent cluster in the UK, but in Germany cluster 2 (Retention of industrial sector) is the most common cluster, followed by cluster 3 (Public sector-oriented). In part these patterns reflect national differences in forms and rates of deindustrialisation(Rosés \& Wolf, 2019; van Neuss, 2018). France also has a relatively high number of regions that belong to cluster 2 , but clusters 6 (Emerging financial and business service centres) and 8 (Growth in retail \& hospitality and public sector) are also very prevalent. Cluster 8 is by far the most common cluster in Spain, Portugal and Greece.

Table 2: Percentage of NUTS3 regions in each country that belong to each cluster

\begin{tabular}{|c|c|c|c|c|c|c|c|c|c|}
\hline Cluster: & $\begin{array}{c}1 \\
\text { Deindus- } \\
\text { triali- } \\
\text { sation } \\
\end{array}$ & $\begin{array}{c}2 \\
\text { Retention } \\
\text { of } \\
\text { industry }\end{array}$ & $\begin{array}{c} \\
\text { Public } \\
\text { sector- } \\
\text { oriented }\end{array}$ & $\begin{array}{c}4 \\
\text { Public } \\
\text { sector } \\
\text { growth } \\
\end{array}$ & $\begin{array}{c}5 \\
\text { Established } \\
\text { fin. \& bus. } \\
\text { Services }\end{array}$ & $\begin{array}{c}6 \\
\text { Emerging } \\
\text { fin. \& bus. } \\
\text { Services }\end{array}$ & $\begin{array}{c}7 \\
\text { Retail \& } \\
\text { hospitality- } \\
\text { oriented }\end{array}$ & $\begin{array}{c}8 \\
\text { Growth in } \\
\text { retail \& } \\
\text { hospitality }\end{array}$ & $\begin{array}{c}\text { Number } \\
\text { of } \\
\text { regions }\end{array}$ \\
\hline Austria & 0.0 & 42.9 & 8.6 & 5.7 & 0.0 & 17.1 & 17.1 & 8.6 & 35 \\
\hline Belgium & 15.9 & 18.2 & 18.2 & 9.1 & 0.0 & 36.4 & 2.3 & 0.0 & 44 \\
\hline Germany (w) & 11.4 & 30.2 & 21.3 & 9.0 & 2.5 & 16.0 & 5.6 & 4.0 & 324 \\
\hline Denmark & 0.0 & 27.3 & 36.4 & 0.0 & 18.2 & 9.1 & 0.0 & 9.1 & 11 \\
\hline Greece & 9.6 & 9.6 & 15.4 & 3.8 & 7.7 & 0.0 & 7.7 & 46.2 & 52 \\
\hline Spain & 11.9 & 13.6 & 5.1 & 5.1 & 3.4 & 10.2 & 13.6 & 37.3 & 59 \\
\hline Finland & 21.1 & 15.8 & 15.8 & 5.3 & 0.0 & 15.8 & 5.3 & 21.1 & 19 \\
\hline France & 12.5 & 25.0 & 6.3 & 5.2 & 3.1 & 24.0 & 3.1 & 20.8 & 96 \\
\hline Ireland & 37.5 & 12.5 & 0.0 & 0.0 & 12.5 & 12.5 & 0.0 & 25.0 & 8 \\
\hline Italy & 10.9 & 16.4 & 16.4 & 1.8 & 0.0 & 25.5 & 7.3 & 21.8 & 110 \\
\hline Luxembourg & 0.0 & 0.0 & 0.0 & 0.0 & 0.0 & 100.0 & 0.0 & 0.0 & 1 \\
\hline Netherlands & 7.5 & 10.0 & 5.0 & 22.5 & 20.0 & 30.0 & 0.0 & 5.0 & 40 \\
\hline Portugal & 16.0 & 20.0 & 12.0 & 0.0 & 0.0 & 4.0 & 4.0 & 44.0 & 25 \\
\hline Sweden & 0.0 & 47.6 & 28.6 & 0.0 & 0.0 & 19.0 & 4.8 & 0.0 & 21 \\
\hline UK & 29.8 & 7.9 & 18.0 & 13.5 & 10.1 & 12.9 & 4.5 & 3.4 & 178 \\
\hline
\end{tabular}

Source: Authors' analysis based on ARDECO data on employment by NACE sector.

\section{What do these findings add to our understanding of 'left behind' regions?}

Of the eight clusters, clusters $1,3,4,7$, and 8 are the ones that show some potentially disadvantageous sectoral compositions and patterns of sectoral change. As will be explained further below, these regions appear to have been less successful in moving towards an economy built on knowledge-intensive services and/or high-end manufacturing, two sectors that tend to be seen as key to regional growth and prosperity (lammarino et al., 2019). Of course, there are important within-sector differences when it comes to the knowledge-intensity, innovativeness, and strategic importance of activities (Eder, 2019; Kemeny \& Storper, 2015). For instance, the financial and business service sector includes a wide range of sub-sectors, each with its own characteristics. It is therefore possible that some regions in these clusters have specialisations in high-productivity sub-sectors within these aggregate sectors. But based on their broad sectoral mix and development, regions in these five clusters possess characteristics that might be considered less desirable. 
Regions in cluster 1 perhaps most closely conform to the typical representation of being 'left behind', in the sense of having experienced shrinking demand for labour in a once-important industrial sector, probably as a result of a combination of technological change and global trade. The damaging effects of large-scale industrial decline have been widely documented, and include increased rates of long-term unemployment and economic inactivity, even until today, as well as population decline in many affected areas (Beatty \& Fothergill, 2020; Daumas et al., 2017; Ragnitz, 2020).

Cluster 3 at first glance appears to represent a less concerning set of regions, given that the public sector provides, in many cases, fairly secure and relatively well-paid employment. However, an over-reliance on the non-market sector can be seen as a sign of weaker regional competitiveness, given that public sector employment is sometimes used by national, regional and local governments as a means to prop up labour demand in relatively disadvantaged regions (Brown et al., 2017; Faggio \& Overman, 2014; Jefferson \& Trainor, 1996). Public sector employment has, in addition, been argued to crowd out private sector employment, though evidence on this is mixed in part due to the difficulty in separating out cause and effect (Becker et al., 2021; Faggio \& Overman, 2014; Jofre-Monseny et al., 2020). Regardless of whether the crowding-out argument holds true, the overrepresentation of public sector employment seen in cluster 3 , along with the underrepresentation of, and modest growth in, financial and business services are unlikely to be generally viewed as a sign of economic strength.

Cluster 4 has similarities to cluster 3 , in the sense that regions in this cluster appear to have become increasingly reliant on public sector employment over time with weaker growth in other sectors. Even so, cluster 4 retains a stronger presence of financial and business service employment relative to the national average, and so perhaps occupies a slightly less disadvantageous position compared to cluster 3 .

Cluster 7, as described above, has a strong specialisation in the 'other private services' sector, which is both not particularly strong in terms of producing tradeable goods and services, and also tends to be characterised by relatively low levels of productivity and pay (Eurostat, 2021b, 2021a). Though cluster 8 did not have an overrepresentation of this sector in 2017 , it has tended to see strong growth in this sector over past decades, suggesting that regions in cluster 8 are perhaps becoming more like those in cluster $7 .{ }^{8}$ Cluster 8 additionally has the lowest location quotient for financial and business services of all the clusters. This sector is the one that contains the largest share of high value-added, knowledge-based activities and jobs (Brown et al., 2017; Capello \& Fratesi, 2013), and as such a low representation of this sector in the regional economy is not generally a positive sign. Further analysis of the structure of employment of regions in cluster 8 reveals that these regions tended to have relatively large specialisations in agriculture, which have diminished over time ${ }^{9}$, suggesting that many of these regions are moving away, at least in employment terms, from a more agriculture-based economy and towards a more servicebased composition of employment. In some regions this decline in agricultural employment may have been partly compensated by an increase in tourism-related activities. The decline of agricultural employment in these regions is of note since the disappearance of traditional agricultural economies has been linked to the emergence of populist sentiments (Mamonova \& Franquesa, 2020).

\footnotetext{
${ }^{8}$ Though a dedicated analysis of the exact sectoral trajectories followed by these regions would have to be conducted to confirm this.

${ }^{9}$ See also appendix A.
} 
Interestingly enough, these five 'concerning' clusters are not evenly distributed across countries. While the UK, Ireland, and to some degree Finland and Belgium, have more than their fair share of deindustrialised (cluster 1 ) regions, regions fitting this same profile of heavy deindustrialisation coupled with low growth in financial and business services are less common in countries such as Austria, Denmark, (western) Germany, the Netherlands and Sweden, again in part reflecting national patterns of structural change (see Table 2). However, these latter countries do have regions with a less favourable patterns of sectoral change. More than a fifth of regions in western Germany, and more than a third of regions in Denmark, are characterised by a long-term and continued overrepresentation of publicsector employment (cluster 3). ${ }^{10}$ Austria has a relatively high percentage of regions that belong to cluster 7 and 8 , which are characterised by a continued and/or growing reliance on the retail and hospitality sector. Cluster 8 similarly represents a large proportion of regions in France, Italy, Ireland, and especially Greece, Spain and Portugal. In these countries (except for Ireland), the dominant type of region that appears to be 'left behind' in terms of sectoral change is in fact the type represented by cluster 8 (Growth in retail \& hospitality).

\section{Regions with more favourable patterns of sectoral change}

In contrast to these five clusters, clusters 2, 5 and 6 appear to have seen more advantageous patterns of structural change, in the sense of being more aligned with the aim of high and increasing levels of tradeable goods and services as well as knowledgeintensive activities. Regions in cluster 2 have been able to maintain sizeable industrial sectors, to a much greater extent than the regions in cluster 1 . While it's difficult to comment on the exact reasons for this, it may be that this continued specialisation in industry has been the result of the resilience of existing sectors or of diversification into new industrial activities (Farinha et al., 2019; Neffke et al., 2011).

Clusters 5 and 6 , in contrast, are characterised by a continued and/or growing overrepresentation of employment in financial and business services. This sector, while varied in composition, contains knowledge-intensive business services (KIBS) as an important subset, which have over recent decades been seen as increasingly important for regional growth (Martin et al. 2021). The separation of a group of regions with a longer-term specialisation in financial and business services and containing well-known service centres such as the City of London, Edinburgh, Dublin, and Frankfurt (cluster 5), from a larger group of regions without such historical specialisation but with substantial growth in financial and business services (cluster 6 ) is consistent with evidence of strong and continued specialisations in business services in capital and other higher-tier cities alongside an increasing dispersal of KIBS throughout European regions over time (Deza \& López, 2014; Merino \& Rubalcaba, 2013; Rosés \& Wolf, 2019). There is some evidence that this dispersal has reverted the concentration of KIBS in the top of the urban hierarchy to a certain extent (Gallego \& Maroto, 2015), which fits with the fact that cluster 6 includes not just a number of large metropolitan areas such as Marseille, Lisbon, Rome, Naples, Amsterdam, and Glasgow, but also many regions centred on medium-sized and smaller cities. It is possible, however, that these smaller cities are predominantly home to lower-order financial and business services, as research has shown that more knowledge-intensive and higher-order services remain concentrated in the largest urban centres (Deza \& López, 2014; Rosés \& Wolf, 2019).

\footnotetext{
10 The public sector accounts for a large share of Danish employment, and plays an equalising role in relation to territorial employment disparities, made possible through substantial fiscal transfers between local areas (F. Hansen \& Jensen-Butler, 1996; H. K. Hansen \& Winther, 2014).
} 


\section{Conclusion: the varied challenges faced by structurally weaker regions}

This paper has shed light on regional variations in sectoral structure and sectoral change in the EU15, paying particular attention to regions which have, over the four decades from 1980 to 2017 , seen less favourable patterns of structural change. To the extent that we can say something about 'left behind' regions based on changing sectoral composition only, this analysis reinforces the idea that such regions come in multiple forms. Not only are there differences between countries in the characteristics of structurally marginalised regions, but, even within the same country, regions with seemingly less advantageous sectoral compositions are marked by substantial differences. In some regions, the decline of formerly important manufacturing and related industries is the dominant challenge. In others, an overspecialisation in relatively low-skilled sectors such as retail and hospitality - sometimes coupled with a declining agricultural sector - appears to be of more concern. Yet other regions are characterised by a persistent or growing reliance on public sector employment and a relatively limited presence of tradeable sectors. This regional sectoral differentiation renders the predicaments and prospects for such places more heterogenous and varied; underlining the importance of more geographically-sensitive approaches to addressing their territorial development aims, prospects, and trajectories.

As argued elsewhere, economic development policy needs to adapt to the circumstances of these different types of regions (MacKinnon et al., 2021; Martin et al., 2021). For instance, in regions characterised by an overrepresentation of the public sector or of lower value-added sectors such as hospitality and retail, addressing productivity, investment and employment conditions in these sectors, rather than purely focussing on expanding the tradeable sector, may offer opportunities to improve living standards as well as economic performance (Evenhuis et al., 2021; Froud et al., 2020). For regions affected by long-term deindustrialisation, a strategy may entail analysing the characteristics of the manufacturing industries that remain in these regions to determine how these might be strengthened, alongside an effort to develop sectors that are complementary to the overall sectoral and skills-profile of these regions.

Of course, to determine the exact needs of different regions, a more comprehensive analysis of their challenges, as well as assets and opportunities, is needed. In future work, we will incorporate sectoral change within a wider analysis of economic, social and demographic indicators, in an effort to provide a more multidimensional understanding of 'left behind' places. 


\section{References}

Aumayr, C. (2006). European Region Types: A Cluster Analysis of European NUTS 3 Regions. 46th Congress of the European Regional Science Association: "Enlargement, Southern Europe and the Mediterranean." https://www.econstor.eu/handle/10419/118543

Baccini, L., \& Weymouth, S. (2021). Gone for Good: Deindustrialization, White Voter Backlash, and US Presidential Voting. American Political Science Review, 115(2), 550567. https://doi.org/10.1017/S0003055421000022

Beatty, C., \& Fothergill, S. (2020). The Long Shadow of Job Loss: Britain's Older Industrial Towns in the 21st Century. Frontiers in Sociology, 5, 54. https://doi.org/10.3389/fsoc.2020.00054

Becker, S. O., Heblich, S., \& Sturm, D. M. (2021). The impact of public employment: Evidence from Bonn. Journal of Urban Economics, 122, 103291. https://doi.org/10.1016/j.jue.2020.103291

Brown, A., Fornoni, R., Gardiner, B., Greunz, L., Jestl, S., Rabemiafara, N., Römisch, R., Stenning, J., \& Ward, T. (2017). Final Report: Economic Challenges of Lagging Regions. In European Commission. European Commission. https://doi.org/10.2776/513206

Capello, R., \& Fratesi, U. (2013). The Service Sector in the New Globalization Phase: Evidence from European Regions. Advances in Spatial Science, 80, 43-64. https://doi.org/10.1007/978-3-642-35801-2_3

Caselli, M., Fracasso, A., \& Traverso, S. (2021). Globalization, robotization, and electoral outcomes: Evidence from spatial regressions for Italy. Journal of Regional Science, 61(1), 86-111. https://doi.org/10.1111/JORS.12503

Consoli, D., \& Sánchez-Barrioluengo. (2019). Polarization and the growth of low-skill service jobs in Spanish local labor markets. Journal of Regional Science, 59(1), 145-162. https://doi.org/10.1111/jors.12409

Daumas, J.-C., Kharaba, I., \& Mioche, P. (2017). La désindustrialisation, une fatalité ? Presses universitaires de Franche Comté.

Delmelle, E. C. (2016). Mapping the DNA of urban neighborhoods: Clustering longitudinal sequences of neighborhood socioeconomic change. Annals of the American Association of Geographers, 106(1), 36-56. https://doi.org/10.1080/00045608.2015.1096188

Deza, X. V., \& López, M. G. (2014). Regional concentration of knowledge-intensive business services in Europe. Environment and Planning C: Government and Policy, 32(6), 10361058. https://doi.org/10.1068/c11171r

Eder, J. (2019). Peripheralization and knowledge bases in Austria: towards a new regional typology. European Planning Studies, 27(1), 42-67. https://doi.org/10.1080/09654313.2018.1541966

Essletzbichler, J., Disslbacher, F., \& Moser, M. (2018). The victims of neoliberal globalisation and the rise of the populist vote: A comparative analysis of three recent electoral 
decisions. Cambridge Journal of Regions, Economy and Society, 11(1), 73-94. https://doi.org/10.1093/cjres/rsx025

Eurostat. (2020). Territorial typologies manual - urban-rural typology. 1-11. https://ec.europa.eu/eurostat/statistics-

explained/index.php?title=Territorial_typologies_manual_-_urban-rural_typology

Eurostat. (2021a). Apparent labour productivity by NACE Rev. 2. Eurostat. https://ec.europa.eu/eurostat/databrowser/view/tin00152/default/table?lang=en

Eurostat. (2021b). Compensation per employee and hours worked per employed person by NUTS 2 regions and by industry. Eurostat.

https://ec.europa.eu/eurostat/databrowser/view/NAMA_10R_2LP10_custom_2029362 $/$ default/table?lang=en

Eurostat. (2022). National accounts employment data by industry (up to NACE $A^{*} 64$ ).

Eurostat.

https://ec.europa.eu/eurostat/databrowser/view/NAMA_10_A64_E_custom_2026341/d efault/table?lang=en

Evenhuis, E., Lee, N., Martin, R., \& Tyler, P. (2021). Rethinking the political economy of place: challenges of productivity and inclusion. Cambridge Journal of Regions, Economy and Society, 14(1), 3-24. https://doi.org/10.1093/CJRES/RSAA043

Faggio, G., \& Overman, H. (2014). The effect of public sector employment on local labour markets. Journal of Urban Economics, 79, 91-107.

https://doi.org/10.1016/j.jue.2013.05.002

Farinha, T., Balland, P. A., Morrison, A., \& Boschma, R. (2019). What drives the geography of jobs in the US? Unpacking relatedness. Industry and Innovation, 26(9), 988-1022. https://doi.org/10.1080/13662716.2019.1591940

Florida, R. (2021). Discontent and its geographies. Cambridge Journal of Regions, Economy and Society. https://doi.org/10.1093/CJRES/RSAB014

Fränti, P., \& Sieranoja, S. (2019). How much can k-means be improved by using better initialization and repeats? Pattern Recognition, 93, 95-112.

https://doi.org/10.1016/J.PATCOG.2019.04.014

Froud, J., Haslam, C., Johal, S., \& Williams, K. (2020). (How) does productivity matter in the foundational economy? Local Economy, 35(4), 316-336. https://doi.org/10.1177/0269094220956952

Gallego, J., \& Maroto, A. (2015). The Specialization in Knowledge-Intensive Business Services (KIBS) across Europe: Permanent Co-Localization to Debate. Regional Studies, 49(4), 644-664. https://doi.org/10.1080/00343404.2013.799762

Hansen, F., \& Jensen-Butler, C. (1996). Economic crisis and the regional and local economic effects of the welfare state: The case of Denmark. Regional Studies, 30(2), 167-187. https://doi.org/10.1080/00343409612331349558

Hansen, H. K., \& Winther, L. (2014). Regional development and the impact of the public sector in Denmark: employment growth and human capital. Geografisk Tidsskrift Danish Journal of Geography, 114(2), 156-168. https://doi.org/10.1080/00167223.2014.952750 
Hedlund, M. (2016). Mapping the Socioeconomic Landscape of Rural Sweden: Towards a Typology of Rural Areas. Regional Studies, 50(3), 460-474.

https://doi.org/10.1080/00343404.2014.924618

Hüther, M., \& Südekum, J. (2019). Vielfalt, Einheitlichkeit oder Gleichwertigkeit? Regionalökonomische Herausforderungen und regionalpolitische. In M. Hüther, J. Südekum, \& M. Voigtländer (Eds.), Die Zukunft der Regionen in Deutschland Zwischen Vielfalt und Gleichwertigkeit. Institut der Deutchen Wirtshaft.

lammarino, S., Rodríguez-Pose, A., \& Storper, M. (2017). Why Regional Development matters for Europe's Economic Future. Regional and Urban Policy Working Papers (European Commission), 7, 1-31.

lammarino, S., Rodriguez-Pose, A., \& Storper, M. (2019). Regional inequality in Europe: evidence, theory and policy implications. Journal of Economic Geography, 19(2), 273298. https://doi.org/10.1093/JEG/LBY021

Jefferson, C. W., \& Trainor, M. (1996). Public sector relocation and regional development. Urban Studies, 33(1), 37-48. https://doi.org/10.1080/00420989650012103

Jofre-Monseny, J., Silva, J. I., \& Vázquez-Grenno, J. (2020). Local labor market effects of public employment. Regional Science and Urban Economics, 82, 103406. https://doi.org/10.1016/J.REGSCIURBECO.2018.11.001

Kemeny, T., \& Storper, M. (2015). Is Specialization Good for Regional Economic Development? Regional Studies, 49(6), 1003-1018. https://doi.org/10.1080/00343404.2014.899691

Kronthaler, F. (2005). Economic capability of East German regions: Results of a cluster analysis. Regional Studies, 39(6), 739-750. https://doi.org/10.1080/00343400500213630

Kühn, M. (2015). Peripheralization: Theoretical Concepts Explaining Socio-Spatial Inequalities. European Planning Studies, 23(2), 367-378. https://doi.org/10.1080/09654313.2013.862518

MacKinnon, D., Kempton, L., O'Brien, P., Ormerod, E., Pike, A., \& Tomaney, J. (2021). Reframing urban and regional 'development' for 'left behind' places. Cambridge Journal of Regions, Economy and Society. https://doi.org/10.1093/CJRES/RSAB034

Mamonova, N., \& Franquesa, J. (2020). Populism, Neoliberalism and Agrarian Movements in Europe. Understanding Rural Support for Right-Wing Politics and Looking for Progressive Solutions. Sociologia Ruralis, 60(4), 710-731. https://doi.org/10.1111/SORU.12291

Martin, R. (2015). Rebalancing the spatial economy: The challenge for regional theory. Territory, Politics, Governance, 3(3), 235-272. https://doi.org/10.1080/21622671.2015.1064825

Martin, R., Gardiner, B., Pike, A., Sunley, P., \& Tyler, P. (2021). Levelling up Left Behind Places: The Scale and Nature of the Economic and Policy Challenge. https://doi.org/10.4324/9781032244341

Merino, F., \& Rubalcaba, L. (2013). Are Knowledge-intensive Services Highly Concentrated? Evidence from European Regions. Tijdschrift Voor Economische En Sociale Geografie, 104(2), 215-232. https://doi.org/10.1111/J.1467-9663.2012.00739.X 
Neffke, F., Henning, M., \& Boschma, R. (2011). How Do Regions Diversify over Time? Industry Relatedness and the Development of New Growth Paths in Regions. Economic Geography, 87(3), 237-265. https://doi.org/10.1111/J.19448287.2011.01121.X

Patias, N., Rowe, F., \& Arribas-Bel, D. (2021). Trajectories of neighbourhood inequality in Britain: Unpacking inter-regional socioeconomic imbalances, 1971-2011. The Geographical Journal. https://doi.org/10.1111/GEOJ.12420

Ragnitz, J. (2020). Strukturwandel nach Entindustrialisierung. In Dossier: Lange Weg der Deutschen Einheit. Bundeszentrale für politische Bildung.

Rodríguez-Pose, A. (2018). The revenge of the places that don't matter (and what to do about it). Cambridge Journal of Regions, Economy and Society, 11(1), 189-209. https://doi.org/10.1093/CJRES/RSX024

Rosés, J. R., \& Wolf, N. (2019). Regional economic development in Europe, 1900-2010: A description of the patterns. In The Economic Development of Europe's Regions: $A$ Quantitative History since 1900. Routledge.

Tyler, P., Evenhuis, E., Martin, R., Sunley, P., \& Gardiner, B. (2017). Growing apart? Structural transformation and the uneven development of British cities. Cambridge Journal of Regions, Economy and Society, 10(3), 425-454. https://doi.org/10.1093/cjres/rsx017

van Neuss, L. (2018). Globalization and deindustrialization in advanced countries. Structural Change and Economic Dynamics, 45, 49-63. https://doi.org/10.1016/J.STRUECO.2018.02.002

Wei, F., \& Knox, P. L. (2014). Neighborhood Change in Metropolitan America, 1990 to 2010. Urban Affairs Review, 50(4), 459-489. https://doi.org/10.1177/1078087413501640 


\section{Appendix A: Difference in results when including all six sectors}

As explained on page 2, two sectors - agriculture and construction - were left out of the analysis.

The main reason for excluding agriculture is the missing data for this sector for more than two-fifths of UK regions, as well as the lack of precision affecting the UK regions for which there is data (figures are rounded to the nearest thousand, which is problematic given that in most UK regions agriculture only employs a few thousand workers).

A second problem is that both agriculture and construction represent, in the majority of regions, a relatively small share of employment. As explained on page 3 , we use location quotients to measure the 1980 and 2017 share of employment in each sector. The small size of the agriculture and construction sectors compared to the other four sectors means that, even in regions with a relatively high location quotient for agriculture or construction, these sectors still only make up a relatively small share of total employment. But in the cluster analysis, location quotients for all sectors are evaluated on an equal basis, and thus a high (or low) location quotient for construction or agriculture may end up driving the clustering results to the same degree as a high (or low) location quotient for the public sector or retail \& hospitality, even though the latter typically make up a much larger share of overall employment. Because of this, including the agriculture and construction sectors in the cluster analysis has a marked effect on the size and characteristics of the clusters that are found compared to when these sectors are left out.

The first notable difference that can be seen when the two additional sectors are included is the emergence of a cluster characterised by a high initial location quotient in construction, but a strong decline in the employment share of this sector between 1980 and 2017, accompanied by growth in the public sector. In other words, a cluster is formed that is very much driven by the construction sector and changes therein, and much less so by changes in other sectors. A second important difference is the emergence of two clusters with high initial specialisations in agriculture. Of these, the first sees a strong decline in agricultural employment between 1980 and 2017, and the second is characterised by a less severe decline in agricultural employment. The first cluster is made up of a large proportion of the regions that belong to cluster 8 in the four-sector clustering (Growth in retail, hospitality and public sector), suggesting that cluster 8 is indeed characterised by shrinkage of a once relatively large agricultural sector. The second cluster is mostly composed of regions from cluster 2 in the four-sector clustering, but with some regions from clusters 3 and 8 , suggesting that at least some of the regions in these three clusters are characterised by relatively high, but somewhat more stable, employment in agriculture. 